3 Reeve H, Baxter K, Newton P, Burkey Y, Black M, Roland M. Long-term follow-up in outpatient clinics. 1: The view from general practice. Fam Pract 1997;14:24-8.

4 Schulpen GJC, Vierhout SPM, Van Der Heijde DM, Landewe RB, Winkens RAG, Winkens AMK, et al. Patients at the outpatient rheumatolog clinic: do they really need to be there? Eur J Intern Med 2003;14:158-61.

5 Damme R van, Drummond N, Beattie J, Douglas G. Integrated care of patients with asthma: views of general practitioners. BrJ Gen Pract 1994; 44:9-13.

6 Mowat AG, Nichols PJ, Hollings EM, Haworth RJ, Aitken LC. A comparison of follow-up regimens in RA. Ann Rheum Dis 1980;39:12-7.

Department of Health. The expert patient: a new approach to chronic disease management for the 21st century. London: Department of Health, 2001.

Williams J, Cheung W, Russell I, Cohen D, Longo M, Lervy B. Open access follow-up for inflammatory bowel disease: pragmatic randomised access follow-up for inflammatory bowel disease: prag

trial and cost effectiveness study. BMJ 2000;320:544-8.
Robinson A, Thompson D, Wilkin D, Roberts C. Guided selfRobinson A, Thompson D, Wilkin D, Roberts C. Guided self-
management and patient-directed follow-up of ulcerative colitis: a randomised trial. Lancet 2001;358:976-81.

10 Pincus T, Callahan L. The side effects of rheumatoid arthritis: destruction, disability and early mortality. Br J Rheumatol 1993;32:28-37

11 Kirwan JR, Snow S. Which patients see a rheumatologist? Br J Rheumatol 1991;30:285-7.

12 Kirwan JR for the former South West Regional Advisory Committee for rheumatology. Rheumatology outpatient workload increases inexorably. Br J Rheumatol 1997;36:481-6.
13 Symmons D, Bankhead C. Health care needs assessment for musculoskeletal diseases: the first step-estimating the number of incident and prevalent cases. Chesterfield: Arthritis Research Campaign, 2002.

14 Hewlett S, Kirwan JR, Mitchell K, Hogg J, Korendovych E, Paine T. Patient-initiated hospital follow-up for rheumatoid arthritis. Rheumatology 2000;39:990-7.

15 Kirwan JR, Mitchell K, Hewlett S, Hehir M, Pollock J, Memel D, et al. Clinical and psychological outcome from a randomised controlled trial of patient-initiated direct access hospital follow-up for rheumatoid arthritis extended to 4 years. Rheumatology 2002;42:422-6.

16 Fries JF, Spitz P, Kraines RG, Holman HR. Measurement of patient outcome in arthritis. Arth Rheum 1980;23:137-45.

17 Ware J, Sherbourne C. The MOS 36 item short form health survey (SF36). Med Care 1992;30:473-83.

18 Zigmond AS, Snaith RP. The hospital anxiety and depression scale. Acta Psychiatr Scand 1983;67:361-70.

19 Stein MJ, Wallston KA, Nicassio PM. Factor structure of the arthritis helplessness index.J Rheumatol 1988;15:427-32.

20 Lorig K, Chastain R, Ung E, Shoor S, Holman H. Development and evaluation of a scale to measure perceived self-efficacy in people with arthritis. Arth Rheum 1989;32:37-44.

(Accepted 27 September 2004)

doi $10.1136 /$ bmj.38265.493773.8F

\title{
Suicide gap among young adults in Scotland: population study
}

Paul Boyle, Daniel Exeter, Zhiqiang Feng, Robin Flowerdew

The number of deaths from suicide increased among young adults between 1981-3 and 1991-3 but fell among older adults. ${ }^{2}$ The gap between such deaths in the most and least deprived areas of Scotland widened during this period, particularly for young adults. We examine changes in suicide rates between 1980-2 and 1999-2001 by area according to deprivation for young men and women to test whether the gap has widened further.

\section{Participants, methods, and results}

The general register office for Scotland provided data on deaths from suicide and undetermined causes for 1980-2 and 1999-2001 (international classification of diseases, ninth revision (ICD-9), codes E950-E959 E980-E989; ICD-10 X60-X84, Y10-Y34, Y87.0). These were aggregated from the postcodes of those who died to about 10000 small areas (CATTs) which are consistent through time. ${ }^{3}$ The suicide rate declined significantly among older adults aged $\geq 45$ years, from 22.99 per 100000 (95\% confidence interval 21.69 to 24.29) in $1980-2$ to 16.73 (15.73 to 17.73$)$ in 1999-2001, but increased significantly from 15.38 (14.38 to 16.38 ) to 24.32 (23.12 to 25.52 ) among younger adults aged 15-44 years. The rate increased significantly from 22.13 (20.43 to 23.83 ) to 38.65 (36.45 to 40.85 ) for young men. The rate also increased in young women but this was not significant (from 8.62 (7.52 to 9.72 ) to 10.55 (9.45 to 11.65$)$ ).

We aggregated areas into fifths of the Carstairs deprivation scores, each fifth containing about a million people in 1981 and 2001. The Carstairs scores ranged between -6.34 and 14.12 in 1981 and -5.94 and 17.47 in 2001. Mortality ratios, standardised to the national age-sex distribution in the 1981 census, were calculated by fifths for both periods.

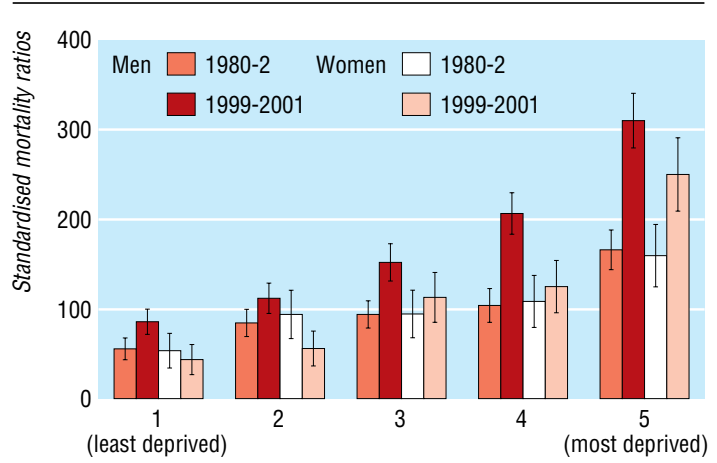

Fifths of deprivation (population weighted)

Suicide among people aged 15-44 years in Scotland according to deprivation: 1980-2 and 1999-2001

For older adults ( $\geq 45$ years), suicide rates declined significantly in all deprivation fifths, and the ratio between the most and least deprived fifths widened slightly from 1.51 (1.26 to 1.81 ) to 1.81 (1.50 to 2.21). The gap widened much more for young adults (15-44 years) from 2.98 (2.4 to 3.72 ) to 4.02 (3.34 to 4.85 ), though this was not significant. It widened from 2.99 (2.31 to 3.87 ) to 3.67 (2.98 to 4.51 ) in young men but from 2.96 (1.95 to 4.50 ) to 5.77 (3.77 to 8.85 ) for young women (figure), explained partly by a fall in suicides in the least deprived fifth for young women that was not seen for young men (unlike 1981, the 2001 standardised mortality ratio was significantly lower for women than men in the lowest fifth). The number of suicides rose considerably more for young men in the

This article was posted on bmj.com on 22 December 2004: http://bmj.com/cgi/doi/10.1136/bmj.38328.559572.55
See also pp 167, 176

School of Geography and Geosciences, University of St Andrews, St Andrews KY16 9ST

Paul Boyle professor of human geography

Daniel Exeter postgraduate student Zhiqiang Feng research fellow

Robin Flowerdew professor of human geography

Correspondence to: P Boyle

P.Boyle@ st-andrews.ac.uk

BMJ 2005;330:175-6 
most deprived fifth, although the 2001 standardised mortality ratio was not significantly higher for men than for women in the highest fifth.

\section{Comment}

The number of suicides increased for young adults in a 20 year period when the number among older adults declined. The rise in standardised mortality ratios was larger for young men $(72.43 \%)$ than young women $(19.04 \%)$. The suicide gap between the most and least deprived areas widened more for young women; there were over six times as many deaths in the most compared with the least deprived fifth in 1999-2001 (152 $v 24)$. For young men the rates rose in every fifth, with a particularly large and significant rise in the most deprived fifth.

Recent media and political attention has focused on rising suicide rates among young men. The relative rise in suicides among young people in poor areas in Scotland, however, has increased during the 1990s and warrants more attention. While suicide polarisation is greater for young women, partly because of declines in the numbers in less deprived areas, the suicide rate in the most deprived fifth is particularly high for young men.

The Scottish Executive aims to reduce the number of suicides by $20 \%$ between 2003 and $2013 .{ }^{4}$ One "priority risk group" is defined geographically as "people in isolated or rural communities." Those in the most deprived areas are not prioritised, although the executive acknowledges that efforts are needed to help vulnerable people in society and address inequalities. Various factors that influence suicide, such as drug

\section{What is already known on this topic}

Suicide is more common in Scotland than in the rest of the United Kingdom, and rates have been rising, particularly among young men

What this study adds

There is a growing social polarisation of suicide among young people in the most deprived parts of Scotland.

misuse, divorce, and unemployment are more common in deprived areas. ${ }^{5}$ Our results suggest that these areas should be targeted among the "priority risk groups" in the future.

Contributors: All authors participated in design, execution, analysis, and writing up of different parts of the study. PB had the main coordinating responsibility for the study design and $\mathrm{DE}$ for the analysis. $\mathrm{PB}$ is guarantor.

Funding: DE was funded by an overseas research studentship award. This research was undertaken as part of his $\mathrm{PhD}$ dissertation.

Competing interests: None declared.

Ethical approval: Not required.

1 McLoone P. Suicide and deprivation in Scotland. BMJ 1996;312:543-4. McLoone P, Boddy FA. Deprivation and mortality in Scotland, 1981 and 1991. BMJ 1994;309:1465-74.

3 Exeter D, Boyle PJ, Feng Z, Flowerdew R, Schierloh N. The creation of 'consistent areas through time' (CATTs) in Scotland, 1981-2001. Population Trends (in press).

4 Scottish Executive. Choose life: a national strategy and action plan to prevent suicide in Scotland. Edinburgh: Stationery Office, 2002.

5 Gunnell D, Frankel S. Prevention of suicide: aspirations and evidence. GMI 1994;308:1227-33.

(Accepted 9 November 2004)

doi 10.1136/bmj.38328.559572.55
See also pp 167, 175

Estonian-Swedish Institute of

Suicidology,

Hariduse 6, Tallinn

10119, Estonia

Airi Värnik

director, professor of

psychiatry

Kairi Kõlves

researcher

Swedish National and Stockholm

County Centre for

Suicide Research

and Prevention of

Mental Ill-Health

(NASP), Karolinska

Institute, Stockholm

Danuta Wasserman

professor of psychiatry

and suicidology

Correspondence to:

A Värnik

Airi.Varnik@ipm.ki.se

BMJ 2005;330:176-7

\section{Suicide among Russians in Estonia: database study before and after independence}

Airi Värnik, Kairi Kõlves, Danuta Wasserman

Migration has been reported as an important risk factor for suicide. Immigrants have a higher risk than exists in their countries of origin and than among the native population of their new country. ${ }^{12}$ According to the 1934 population census, before the second world war native Estonians constituted $88.1 \%$ of the total population of Estonia. By 1989, however, because of geopolitical changes related to the incorporation of Estonia into the Soviet Union, the Russian minority had grown to about $30 \%$. We examined how the radically changed sociopolitical status of the Russian minority after the dissolution of the Soviet Union was reflected in their suicide rates.

\section{Methods and results}

We compared suicide rates of Russians in Estonia, Estonians in Estonia, and inhabitants of Russia from before (1983-90) and after the dissolution of the Soviet Union during Estonian independence (1991-8). We collected data from the World Health Organization reports on age adjusted suicide rates for the Russian Federation. We derived data on the population in Estonia by nationality from the Estonian Statistical Office. The nationality of those who committed suicide was specified on the death certificates.

According to the 1989 census, Estonian-Russians include Russians (78.7\%), Ukrainians (8.1\%), Belorussians $(4.7 \%)$, and others $(8.5 \%)$. We termed inhabitants of Russia "Russians" in the study. In the Russian Federation $82.6 \%$ of inhabitants were native Russians.

Means of age adjusted suicide rates were high for the three nationalities during 1983-90 (table). The rates of suicide were lower among Russians in Estonia than Estonians $(\mathrm{P}=0.061)$. During the transition period (1991-8), suicide rates increased for all three nationalities (by 39.2\% for Russians in Estonia, 25.9\% for Russians in Russia, and 17.1\% for Estonians) (table). Thus, the Estonian Russians had a significantly higher

This article was posted on bmj.com on 15 December 2004: http://bmj.com/cgi/doi/10.1136/bmj.38328.454294.55 